\title{
The Market For Audit Services In Germany
}

Daniel T. Simon, (E-mail: dbandurs@nd.edu), University of Notre Dame

\begin{abstract}
Many studies have been conducted on the market for audit services in the United States, the United Kingdom, Australia and other countries, but many countries, including Germany, have not been studied. Since the German accounting environment differs significantly from most of the countries previously studied, this paper studies the audit services market in Germany to ascertain whether the determinants of audit fees differ in Germany. The findings indicate broad similarities with some differences in the market for audit services in Germany and countries previously studied. In particular, as in a majority of countries previously studied, there is a fee premium paid to large auditors.
\end{abstract}

\section{INTRODUCTION}

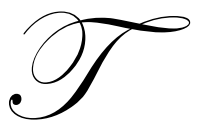

his paper extends prior research into the market for audit services by providing a study of the market for audit services in Germany, a country which has not been studied in audit fee research. Understanding the similarities and differences between the market for audit services in Germany and other nations should increase our knowledge of the increasingly interdependent world economy as it relates to accounting. It will also increase our knowledge of the economics of auditing. The similarity of audit fee determinants between Germany and other countries is analyzed and the extent to which the large audit firm fee premium documented in other countries exists in Germany is examined. This will extend our knowledge of accounting in Germany and allow assessment of the similarities and differences in the market for audit services in Germany and other countries.

The remainder of this paper proceeds as follows. In the next section the results of previous research on the market for audit services in other countries is briefly reviewed. This is followed by a discussion of the institutional background of accounting and auditing in Germany. The next section describes the data and the empirical tests. Then the results are presented. The results are discussed and summarized in the final section of the paper.

\section{PREVIOUS RESEARCH}

Beginning with the seminal work of Simunic (1980), a number of studies have analyzed the market for audit services in several countries. The majority of these studies have focused on a few countries--the United States, the United Kingdom, and Australia. To date only limited attention has been given to the market for audit services in other countries. The major results of earlier studies have served to establish the responsiveness of audit fees to variables related to auditee size, audit risk, and audit complexity. In general, these papers have found that these variables explain a large proportion of audit fees.

An additional question which has often been addressed in prior studies is whether some auditors receive premium fees due to their "brand name" or reputation for providing high quality audits. Usually these studies have explored whether there is an audit fee premium paid to "Tier I" auditors, with the term Tier I usually defined as consisting of the very largest international accounting firms. Typically this group of firms has been viewed as being comprised of the so-called "Big Eight" or "Big Six" (now the "Big Four", following several mergers and the recent demise of Arthur Andersen) international firms. The importance of finding a Tier I audit fee premium is that it provides evidence of product differentiation in the market for audit services. That is, firms which have invested in reputation capital (e.g., employee training programs, firm publications, and advertising) may be able to obtain a return on this investment through higher prices for their services. To date a Tier I fee premium has been documented in the 
United States (Palmrose, 1986; Francis and Simon, 1987; Simon and Francis, 1988; Turpen, 1990), the United Kingdom (Taffler and Ramalinggam, 1982; Chen et al., 1993; Brinn et al., 1994), Australia (Francis, 1984; Francis and Stokes, 1986; Craswell and Francis,1999), India (Simon et al., 1986), Bangladesh (Karim and Moizer, 1996), Japan (Taylor, 1997), Nigeria (Taylor and Simon 2003), Ireland (Taylor and Simon, 2002), Hong Kong, and Singapore (Simon et al., 1992). Studies of New Zealand (Firth 1985) and Malaysia (Simon et al., 1992) did not provide evidence of a Tier I audit fee premium. Studies of the Canadian audit services market have been mixed: Anderson and Zéghal (1994) found a Tier I fee premium while Chung and Lindsay (1988) did not. A recent study of Pakistan (Basioudis and Fifi, 2004) provided additional evidence that a Tier I fee premium is not universal; while the pricing models used in prior literature fit the data, there was no evidence of a fee premium to large audit firms. Thus, it is possible that the market for audit services may differ significantly across countries, with a general Tier I audit fee premium characterizing only certain countries. That is, the inconclusive results of previous studies suggest that the degree of auditor product differentiation may vary significantly across countries.

Since there have been inconclusive results, examining a country, Germany, previously not studied in this line of research, will extend our knowledge of the market for audit services and provide further evidence on the prevalence of the large audit firm fee premium. Moreover, since Germany is one of the world's largest economies, a knowledge of this market is worthwhile in and of itself. Another value of studying the German audit market is that most prior studies have focused on the United States or on current or former members of the United Kingdom. Since the German accounting and auditing environment differs from that of the U.S. and the U.K., there may be differences in the determinants of audit fees.

\section{INSTITUTIONAL BACKGROUND}

The accounting and auditing environment in Germany differs from that in previously studied countries, especially current and former members of the British Commonwealth. For example, one well-known taxonomy (Nair and Frank, 1980) classified Germany as best described by the "Continental European model,"(as opposed to the British Commonwealth, Latin America, and United States models) based on accounting measurement and disclosure practices. This conclusion was similar to that reached in an earlier study by DaCosta et al. (1978) which also found Germany in a classification cluster different from what they termed the "Commonwealth group." Another result indicating that Germany was distinct from many other countries was suggested by a classification scheme which hypothesized that the legal system of a country is a good predictor of its accounting orientation (Salter and Doupnik, 1992); this study placed Germany in its own category separate from all of the other countries studied. Similarly, a study based on the content of the auditor's report (Hussein, et al., 1986), classified Germany (along with Austria) into a group distinct from the U.S., the U.K., and most other European nations. A study of financial disclosure regulation (Cooke and Wallace, 1990) suggests that Germany can be described as "regulated" but not among the most "highly regulated" developed countries such as the United States and the United Kingdom. A study of disclosure practices (Gray and Vint, 1995) ranked Germany as eighth highest of 27 countries in terms of the extent of financial statement disclosures as reported by a survey of Deloitte Haskins and Sells partners conducted in 1982-1983. Germany's mean disclosure index was 2.4, which was closer to the two highest countries ranked on this index (United States, 3.1; the United Kingdom, 2.8) than to the lowest disclosure countries (Columbia, Portugal, and Uruguay which had indices of $1.1)$.

There are also differences in the history of the accounting profession in Germany. As a recent history of the profession in Germany (Markus, 1997) notes, the accounting profession in most English-speaking countries developed gradually in periods of general economic growth and political stability; in contrast the profession in Germany is of more recent origin and developed in the period of instability following World War I. There are also differences in the way audits are conducted in Germany. For example, while many auditing practices are similar to other countries, there are numerous differences in emphasis; for example in Germany relatively more emphasis is placed on detailed substantive tests of financial statement items as compared with the tendency in many other countries to rely on clients' internal controls to reduce such tests (Kroneberger and Combrink, 1991). One similarity between Germany and other countries is the importance of the large international accounting firms in the audit services market. All of the Big Five (at the time of the data used in this paper) accounting firms had a significant presence in Germany (Marcus, 1997; 
Ashbaugh and Warfield, 2003). An important empirical question to be investigated in this paper is whether these large auditing firms receive a fee premium as has been documented in studies of many other countries.

Thus, in terms of its general accounting policy orientation, Germany is at least somewhat different from many of the other countries examined in prior studies of the market for audit services. This suggests the possibility that the determinants of audit fees in Germany may differ from those of countries previously studied. The similarities and differences in the audit services market in Germany will be examined in the remainder of the paper.

\section{DATA AND METHODOLOGY}

A potential sample of 300 German industrial and commercial firms was identified from Moody's International Manual. Since audit fees are not required disclosure in financial statements in Germany (as they are in most British Commonwealth countries and in the United States), it was necessary to obtain audit fee data by means of questionnaires. A letter in German was sent to each selected firm requesting copies of their annual reports for years 2000 and 2001 and requesting that they also divulge the fees paid to their auditors for those years. ${ }^{1}$ The final sample used in this study consisted of 116 observations on 66 different auditees in the period 2000-2001.

The basic research approach relies upon a regression model of audit fees similar to those used in most prior studies of audit fees. Typically, as in this paper, audit fee has been placed as a dependent variable to be explained by various characteristics of the client. Among the client characteristics found most important in previous studies have been size and variables related to the complexity of the audit, such as the number of subsidiary firms and the relative proportion of assets that require more auditor effort to verify (e.g., inventory and receivables). These models have consistently been found to explain a considerable proportion of audit fees in studies of Canada, the United States, the United Kingdom, Australia, New Zealand, Hong Kong, Malaysia, Singapore, and India. This basic regression model will therefore serve as a useful benchmark for assessing the similarities and differences in the audit services market in these countries as compared to Germany.

The basic regression model is of the following form:

\section{AUDIT FEE $\quad=b_{1}+b_{2}$ ASSETS $+b_{3}$ SUBSIDIARIES $+b_{4}$ INVREC $+b_{5}$ LOSS $+b_{6}$ BIG5}

Where

\begin{tabular}{|c|c|c|}
\hline AUDIT FEE & $=$ & audit fee paid to the independent auditor \\
\hline ASSETS & $=$ & total assets of the client \\
\hline SUBSIDIARIES & $=$ & the number of consolidated subsidiaries \\
\hline INVREC & $=$ & $\begin{array}{l}\text { the proportion of total assets represented by inventories and receivables, i.e., (inventories + } \\
\text { receivables)/(total assets) }\end{array}$ \\
\hline LOSS & $=$ & an indicator variable which has a value of one if the firm had a loss in the current year \\
\hline BIG5 & $=$ & $\begin{array}{l}\text { an indicator variable which has a value of one if the company is audited by a Big Five audit } \\
\text { firm }\end{array}$ \\
\hline
\end{tabular}

The first explanatory variable (ASSETS) represents the size of the audit client. Auditee size is clearly an important determinant of audit fees since larger clients will require more audit effort. ${ }^{2}$ The next two variables (SUBSIDIARIES and INVREC) relate to audit risk and audit complexity. For example, more subsidiaries and a greater proportion of assets which are difficult to audit such as inventory and receivables will require more auditor effort and hence increase fees. Therefore, ASSETS, SUBSIDIARIES, and INVREC should be positively related to audit fees. The variable LOSS proxies for client and auditor risk. Risk is higher for these clients since they have suffered financial losses leading to higher likelihood of bankruptcy or decline in stock price and therefore greater likelihood of litigation against both client and auditor. Therefore, LOSS is expected to be positively related to audit fees as has been found in studies of other countries (e.g., Simon and Francis, 1988; Craswell and Francis, 1999). Prior studies (for a summary, see Simon et al., 1992) find that the Big Eight or Big Five (now the Big Four) auditors receive 
premium fees in many countries, perhaps due to a perception of higher quality associated with their audits. Therefore, the BIG5 variable is used to control for the effect of audit firm type on audit fees. This variable assesses the extent, if any, of a large audit firm fee premium as an indication of the degree of product differentiation in Germany. Based upon research findings for other countries, this variable is expected to be positively related to audit fees. That is, while not all previous studies have found positive evidence of a large audit firm fee premium, no studies to date have found a fee discount on audits performed by large audit firms.

\section{EMPIRICAL RESULTS}

Table 1 presents descriptive statistics for the sample. Considerable differences in the client-specific explanatory variables (e.g., ASSETS, INVREC) exist, allowing for enough variation to test the basic regression hypotheses.

Table 2 presents the results of the basic regression equation which is similar to those used in studies of other countries. The overall results suggest a good linear fit in which a large proportion of the variation in audit fees is explained. The value of the F-statistic is significant at better than the .001 level. The value of adjusted $\mathrm{R}^{2}$ is .74 , indicating that the model explains approximately three-fourths of audit fees. This value of the $\mathrm{R}^{2}$ statistic is similar in magnitude to those found in studies of other countries. ${ }^{3}$

An examination of the t-statistics for the individual explanatory variables also suggests considerable similarity between the determinants of audit fees in Germany and countries studied in previous research. The client size variable (ASSETS) was statistically significant at better than the .001 level as was the audit complexity variables, SUBSIDIARIES. However, the audit complexity variable, INVREC, which has been found significant in almost all studies of the other countries was not significant in Germany. The audit risk variable LOSS was positive and significant at the .05 level. Thus, with one important exception (INVREC), the results for the auditee size, audit complexity and audit risk variables indicate that there is considerable similarity in the determinants of audit fees in Germany and the countries studied in previous research. The auditor-size variable, BIG5, was statistically significant, suggesting that there is an audit fee premium paid to large accounting firms in Germany, as has been found in most other countries studied.

\section{SUMMARY AND CONCLUSIONS}

The results demonstrate that most of the auditee size, audit risk, and audit complexity variables found to be important in studies of other countries are also important in explaining audit fees in the German context. One important exception, the audit complexity variable for inventory and receivables, was found not to be significantly related to audit fees. However, with this exception, after controlling for auditee size, audit risk, and audit complexity, the experimental variable of primary interest, auditor size, was highly significant. Thus, even though the German accounting environment differs from the majority of countries previously studied, the large audit-firm fee premium exists in Germany as it does in most other countries.

\section{REFERENCES}

1. Anderson, T. and D. Zéghal. 1994. The pricing of audit services further evidence from the Canadian market. Accounting and Business Research (summer):195-207.

2. Ashbaugh, M. and T.D. Warfield. 2003. Audits as a corporate governance mechanism: evidence from the German market. Journal of International Accounting Research (2):1-21.

3. Basioudis, I.G. and F. Fifi. 2004. The market for professional services in Indonesia. International Journal of Auditing (July):153-164.

4. Brinn, T., M. Peel, and R. Roberts. 1994. Audit fee determinants of independent and subsidiary unquoted companies in the UK--an exploratory study. British Accounting Review (26): 101-121.

5. Chen, P., M. Ezzamel, and D. Gwillian. 1993. Determinants of audit fees for quoted UK companies. Journal of Business Finance and Accounting (November):765-786. 
6. Chung, D. and W. Lindsay. 1988. The pricing of audit services: the Canadian perspective. Contemporary Accounting Research (fall):19-46.

7. Cooke, T. and R. Wallace. 1990. Financial disclosure regulation and its environment: a review and further analysis. Journal of Accounting and Public Policy (summer):79-110.

8. Craswell, A.T. and J.R. Francis. 1999. Pricing initial audit engagements: a test of competing theories. Accounting Review (April):201-216.

9. DaCosta, R., J. Bourgeois, and W. Lawson. 1978. A classification of international and financial accounting practices. International Journal of Accounting Education and Research (17):73-85.

10. DeAngelo, L. 1981. Auditor independence, low-balling and disclosure regulation. Journal of Accounting and Economics (August):113-127.

11. Firth, M. 1985. An analysis of audit fees and their determination in New Zealand. Auditing: A Journal of Practice and Theory (Spring):23-37.

12. Francis, J. 1984. The effect of audit firm size on audit prices. Journal of Accounting and Economics (August):133-151.

13. Francis, J. and D. Simon. 1987. A test of audit pricing in the small-client segment of the U.S. audit market. Accounting Review. (January):145-157.

14. Francis, J. and D. Stokes. 1986. Audit prices, product differentiation, and scale economies: further evidence from the Australian market. Journal of Accounting Research (autumn):383-393.

15. Gray, S. and M. Vint. 1995. The impact of culture on accounting disclosures: some intentional evidence. Asia-Pacific Journal of Accounting (December):33-43.

16. Hussein, M., V. Bavishi and J. Gangolly. 1986. International similarities and differences in the auditor's report. Auditing: A Journal of Practice and Theory (Fall):124-133.

17. Karim, A. and P. Moizer. 1996. Determinants of Audit Fees in Bangladesh. International Journal of Accounting 31:497-509.

18. Kroneberger, W. and P. Combrink. 1991. Accounting and auditing in Germany. Frankfurt:TreuhandVereinigung.

19. Markus, H. 1997. The history of the German public accounting profession. New York:Garland Publishing.

20. Nair, R. and W. Frank. 1980. The impact of disclosure and measurement practices on international accounting classifications. Accounting Review (July):426-450.

21. Palmrose, Z. 1986. Audit fees and auditor size: further evidence. Journal of Accounting Research (spring): 97-110.

22. Salter, S. and T. Doupnik. 1992. The relationship between legal systems and accounting practices: a classification exercise. Advances in International Accounting, Vol. 5, edited by K.S. Most. Greenwich, CT: JAI Press.

23. Simon, D. and J. Francis. 1988. The effects of auditor changes on audit fees: tests of price cutting and price recovery. Accounting Review (April):255-269.

24. Simon, D., R. Ramanan and A. Dugar. 1986. The market for audit services in India: an empirical examination. International Journal of Accounting Education and Research (spring):27-35.

25. Simon, D., S. Teo and G. Trompeter. 1992. A comparative study of the market for audit services in Hong Kong, Malaysia and Singapore. International Journal of Accounting Education and Research 27:234-240.

26. Simunic, D. 1980. The pricing of audit services: theory and evidence. Journal of Accounting Research (spring), 161-190.

27. Taffler, R. and K. Ramalinggam. 1982. The determinants of the audit fee in the U.K.: an exploratory study. Working paper, City University Business School, London.

28. Taylor, M. 1997. The market for audit services in Japan. The Pacific Accounting Review (December):59-74.

29. Taylor M. and D. Simon. 1999. Determinants of Audit Fees: The Importance of Litigation, Disclosure, and Regulatory Burdens in Audit Engagements in 20 Countries. International Journal of Accounting.

30. Taylor M. and D. Simon. 2002. The Market for Audit Services in Ireland. International Journal of Auditing.

31. Taylor M. and D. Simon. 2003. The Market for Audit Services in Nigeria. Research in Accounting in Emerging Economies.

32. Taylor, M., D. Simon, and G. Burton. 1999. A survey of Audit Pricing in South Korea. Research in Accounting Regulation. 
33. Turpen, R. 1990. Differential pricing on auditors' initial engagements: further evidence. Auditing: A Journal of Practice and Theory (Spring):60-76.

\section{ENDNOTES}

1. I am grateful to my research assistant, Birgit Heinish, for translating the request for information into German, as well as gathering the data from the German language financial statements. Her knowledge of both accounting and German was indispensable.

2. Logarithmic transformations of audit fees and client assets are employed because previous research (e.g., Francis and Simon, 1987) indicates that this specification provides a good linear fit in which the assumptions of ordinary least squares regression are satisfied. A square root transformation of subsidiaries was done for the same econometric reason. None of these transformations affected the basic results reported in the paper. Details are available from the author on request.

3. Values of $\mathrm{R}^{2}$ for studies of audit fees are typically in the range of .60 to .70 .

Table 1: Descriptive Statistics

\begin{tabular}{|l|c|}
\hline \multicolumn{1}{|c|}{ Variable } & Mean (Std. Dev.) \\
\hline \multirow{2}{*}{ Audit Fee (thousands of Euros) } & 820 \\
& $(3700)$ \\
\hline \multirow{2}{*}{ Assets (millions of Euros) } & 1161 \\
& $(4582)$ \\
\hline \multirow{2}{*}{ Subsidiaries } & 9.9 \\
& $(14.3)$ \\
\hline \multirow{2}{*}{ Proportion of Assets in Inventory and Receivables } & 0.36 \\
\hline Percentage of Firms reporting losses & $(.24)$ \\
\hline Percentage of Firms audited by: & $18.9 \%$ \\
\hline Big Five Auditors & \\
Other Auditors & $59.5 \%$ \\
\hline
\end{tabular}

Table 2: Regression Results for Basic Model

\begin{tabular}{|c|c|}
\hline \multicolumn{2}{|c|}{$(n=116)$} \\
\hline Variable & $\begin{array}{l}\text { Coefficient } \\
\text { (t-statistic) }\end{array}$ \\
\hline INTERCEPT & $\begin{array}{c}1.88 \\
(8.03)^{* * *}\end{array}$ \\
\hline ASSETS & $\begin{array}{c}.43 \\
(9.12)^{* *}\end{array}$ \\
\hline INVREC & $\begin{array}{c}-.41 \\
(1.33)^{\mathrm{ns}}\end{array}$ \\
\hline SUBSIDIARIES & $\begin{array}{c}.31 \\
(7.07)^{* *}\end{array}$ \\
\hline LOSS & $\begin{array}{c}.31 \\
(1.66)^{*}\end{array}$ \\
\hline BIG5 & $\begin{array}{c}.35 \\
(2.41)^{*}\end{array}$ \\
\hline Adjusted $\mathrm{R}^{2}$ & .74 \\
\hline F-Statistic & $64.82 * *$ \\
\hline $\begin{array}{ll}* & \text { Not Significant } \\
\text { Significant at the } .05 \text { level. } \\
\text { Significant at the } .001 \text { level. }\end{array}$ & \\
\hline
\end{tabular}


